CLINICAL STUDY

\title{
Influence of androgens and age on androgen receptor and $5 \alpha$-reductase II transcription
}

\author{
Olaf José-Carlos Hellwinkel, Anke Müller ${ }^{1}$, Dagmar Struve and Olaf Hiort \\ Department of Pediatrics and ${ }^{1}$ Department of Pathology, Medical University of Lübeck, Germany \\ (Correspondence should be addressed to O Hiort, Department of Pediatrics, Medical University of Lübeck, Ratzeburger Allee 160, D-23538 Lübeck, \\ Germany; Email: hiort@paedia.ukl.mu-luebeck.de)
}

\begin{abstract}
Objective: The regulation of the androgen receptor (AR) and $5 \alpha$-reductase II (5RII) gene in genital skin fibroblasts is of particular interest in understanding androgen-dependent embryonic formation of external male genitalia.

Design: Human genital skin fibroblasts from pre- and postpubertal male individuals (aged 5 months to 51 years) were incubated with testosterone and dihydrotestosterone under various conditions to study the regulation of $A R$ and $5 \mathrm{RII}$ transcript concentrations dependent on androgen concentration and donor age.

Methods: A competitive reverse transcribed PCR (RT-PCR) protocol was designed to achieve simultaneous relative quantification (semi-quantification) of AR and 5RII mRNAs in standardized whole RNA samples from each donor.

Results: Concentrations of AR and 5RII mRNAs are not influenced by androgens in genital skin fibroblasts. Moreover, comparison of AR transcript concentrations in genital skin fibroblast cell lines revealed weak variations independent of donor age, while 5RII transcription exhibited clear individual differences with a declining tendency towards higher ages.

Conclusions: The transcription of AR and 5RII is not directly regulated by testosterone or dihydrotestosterone in pre- or postpubertal human genital skin fibroblasts. However, donor age seems to play a role in gradual depression of 5RII transcription.
\end{abstract}

European Journal of Endocrinology 143 217-225

\section{Introduction}

The androgen receptor (AR) and $5 \alpha$-reductase II (5RII) play a crucial role in the development of the male reproductive tract. In normal male individuals, the AR first recognises and binds the androgens testosterone (T) or dihydrotestosterone (DHT) within the cytoplasm of androgen target cells. Then it dimerizes and migrates into the nucleus where it binds with cofactors to the promoter of androgen sensitive target genes initiating the appropriate cell response (1-3). During urogenital ontogenesis, T-AR complexes induce the virilization of the Wolffian ducts. In fibroblasts of the sinus urogenitalis and genital folds, T is first reduced to DHT by the enzyme 5RII, then development of external genitalia is initiated by the AR-DHT complex (4).

In various cell types androgens seem to excite an influence on AR and 5RII expression in different and sometimes even contradicting manners. This occurs particularly at the transcription level. In rat ventral prostate, 5RII expression is enhanced by DHT (5), while AR transcription in this and other tissues (epididymis, vas deferens, kidney and brain) is up-regulated in castrated rats, probably due to $\mathrm{T}$ depletion (6). In smooth muscle cells from rat penis (7) and in hamster harderian gland cells (8), androgens enhance AR transcription. In the human prostate cancer cell line LNCaP, androgens repress AR transcription, but enhance AR protein stability $(9,10)$. As genital skin fibroblasts (GSFs) are crucial for androgen-dependent development of male external genitalia, normal expression of AR and 5RII is of considerable importance. Therefore we focused our study on the effect of $\mathrm{T}$ and DHT on AR and 5RII transcription in cultured GSFs from pre- and postpubertal individuals; additionally, age-dependent individual differences of AR or 5RII mRNA concentrations in GSFs from several normal males were investigated.

\section{Materials and methods}

\section{Cell culture}

Foreskins from 10 normal prepubertal boys and two adult fertile men of varying ages were obtained at 
circumcision, dissected mechanically, and incubated in medium (DMEM-F12, 5\% $\mathrm{CO}_{2}, 10 \%$ charcoal-stripped fetal calf serum, antibiotics) at $37^{\circ} \mathrm{C}$ to culture genital skin fibroblasts (GSFs). Cells of the second passage were stored in liquid nitrogen for later experiments. After thawing, GSFs were first grown to approximately $80 \%$ confluence and then pre-incubated in medium without androgens for $48 \mathrm{~h}$. Cells were afterwards incubated in medium containing varying $\mathrm{T}$ or DHT concentrations for ascending periods (Table 1). Finally, GSFs were submitted to RNA isolation. Our studies were approved by the local Ethics Committee and informed consent had been obtained from adult patients or the parents of minors.

\section{RNA analysis}

Whole RNA from GSFs was isolated using RNeasy columns according to the manufacturer's instructions (Quiagen, Hilden, Germany). RNA was quantified photometrically (absorbency at $260 \mathrm{~nm}$ measured in a DNA/ RNA calculator from Pharmacia, Freiburg, Germany). To determine the quality and integrity of RNA, $5 \mu \mathrm{l}$ aliquots were electrophoresed on formaldehydedenaturing 1\% agarose gels (11). Standardization of whole RNA from different GSF cultures was performed by RT-PCRs for ubiquitous ribosomal protein L7 transcription with modified primers L7neus (5'-GGA ACC ATG GAG GGT GTA GA-3') and L7neua (5'-GAA AAA TAA TCA TGG TAG AC-3') as previously described (12). The amplification procedure was stopped after 21 cycles, i.e. within the exponential phase of the PCR, as found by preliminary experiments (not shown). Samples were analyzed for equivalent amplification product concentration on $2 \%$ agarose gels (13).

\section{Construction of artificial standards (competitors) and semi-quantitative competitive RT-PCR}

Standardized cDNA synthesis and PCR for all investigated RNA samples was performed with the addition of artificial standards (competitors). Competitors share primer complementary sequences with the target amplicons of AR and 5RII transcripts to allow similar amplification behaviour and direct competition of target and competitor for the primers during the PCR step. This represents the basis for the quantification experiments described here. Competitors were constructed as described by Celi et al. (14). Briefly, GSF whole RNA was first reverse transcribed by poly-dT priming and then submitted to PCRs using the following composite primers: antisense primer hARE3a-AR IIaComp (5'ACT ACA CCT GGC TCA ATG GCC CAG AGT CAT CCC TGC TTC A-3') and sense primer T7-AR IsComp (5'TAA TAC GAC TCA CTA TAG GGA GTG GAT GGA TAG CTA CTC CGG $-3^{\prime}$ ) for the construction of the AR competitor; antisense primer 5RIIE 2a-4aComp (5'-GTG
GCC AGG GCA TAG CCG ATC TGT GTA CCA CCC ATC AGG G-3') and sense primer T7-5RII E1 SIIsComp (5'TAA TAC GAC TCA CTA TAG GGA GAG CTG CCT TCC TTC GCG GTG-3') for the construction of the 5RII competitor. With these primers, PCR products were generated which are $155 \mathrm{bp}$ (AR) and $176 \mathrm{bp}$ (5RII) shorter than the respective target amplicons. By their sense composite primers, shortened PCR products were tailed at their $5^{\prime}$-end with a T7 RNA polymerase recognition sequence. Products were in vitro transcribed with T7 RNA polymerase (Promega, Heidelberg, Germany) and digested twice with DNase (Gibco-BRL, Ludwigshafen-Leopoldshausen, Germany) according to the manufacturer's instructions. RNA competitors were quantified and finally diluted to obtain working stock aliquots for further usage in semi-quantitative competitive RT-PCRs.

Simultaneous reverse transcription (RT) of AR/5RII transcripts and competitors was achieved by specific antisense priming. Whole RNA $(1 \mu \mathrm{g})$ from each GSF sample was mixed with both AR- and 5RII-RNA competitors in variable concentrations (Figs 1 and 2) in one reaction tube. Twenty picomoles of each AR and 5RII antisense primer and DEPC- $\mathrm{H}_{2} \mathrm{O}$ were added to a final volume of $10 \mu \mathrm{l}$. Mixtures were incubated at $70^{\circ} \mathrm{C}$ for $5 \mathrm{~min}$. Then, $1 \times$ first-strand buffer, $1 \mathrm{mM}$ dNTPs, $10 \mathrm{mM}$ DTT and 10U RNase inhibitor (BoehringerMannheim, Mannheim, Germany) were added to a final volume of $20 \mu \mathrm{l}$. Reverse transcription was performed with 40U Superscript II RT (Gibco BRL) at $37^{\circ} \mathrm{C}$ for $1 \mathrm{~h}$. For AR, an exon-spanning fragment of the target transcript stretching from nucleotide position 1653 (according to Lubhahn et al. (15)) in exon 1 to position 2845 in exon 4 was amplified from $1 \mu \mathrm{l}$ cDNA samples. PCR solutions contained $20 \mathrm{pmol}$ sense primer AR Is (5'-TGG ATG GAT AGC TAC TCC GG-3') and antisense primer AR IIa (5'-ACT ACA CCT GGC TCA ATG GC - $\left.3^{\prime}\right)$ (16), $200 \mu \mathrm{M}$ dNTPs, $1 \times$ PCR buffer $(50 \mathrm{mM} \mathrm{KCl} ; 20$ $\mathrm{mM}$ Tris, $\mathrm{pH}$ 9.0; $50 \mu \mathrm{g} / \mathrm{ml} \mathrm{BSA}$ ), $1.0 \mathrm{mM} \mathrm{MgCl}_{2}$ and $1 \mathrm{U}$ Ampli-Taq DNA polymerase (Perkin-Elmer, Weiterstadt, Germany). Cycling conditions were: $75 \mathrm{~s}$ denaturation at $94{ }^{\circ} \mathrm{C}, 90 \mathrm{~s}$ primer annealing at $60^{\circ} \mathrm{C}$ and $120 \mathrm{~s}$ primer extension at $72{ }^{\circ} \mathrm{C}$ for 35 cycles. For 5 RII, the amplicon reached from the amino acid coding nucleotide at position 170 in exon 1 to the nucleotide at position 623 in exon 4 (according to Labrie et al. (17)). Amplification was performed with each 20 pmol sense primer 5RII E1SIIs (5'-AGC TGC CTT CCT TCG CGG TG$\left.3^{\prime}\right)$ and antisense primer 5RII E4a (5'-GTG GCC AGG GCA TAG CCG AT-3'), $200 \mu \mathrm{M}$ dNTPs, $1 \times$ PCR buffer (50 mM KCl; 20 mM Tris, pH 8.6; $50 \mu \mathrm{g} / \mathrm{ml} \mathrm{BSA}$ ), 0.75 $\mathrm{mM} \mathrm{MgCl}$ and $1 \mathrm{U}$ Ampli-Taq DNA polymerase. The cycling conditions were: $75 \mathrm{~s}$ denaturation at $94^{\circ} \mathrm{C}, 90 \mathrm{~s}$ primer annealing at $66^{\circ} \mathrm{C}$ and 120 seconds primer extension at $72^{\circ} \mathrm{C}$ for 32 cycles. Non-denatured PCR products (AR target: $479 \mathrm{bp}$; AR standard: $324 \mathrm{bp}$; $5 \mathrm{RII}$ target: $454 \mathrm{bp}$; 5RII standard: $278 \mathrm{bp}$ ) were electrophoresed on non-denaturating polyacrylamide gels (PAA 
gels) subsequently silver-stained as previously described $(18,19)$ and quantified by computerized densitometry (ImageMaster, Pharmacia). Finally, densities of target and standard bands were compared with each other resulting in a dimensionless ratio $\mathrm{A}(\mathrm{t} / \mathrm{s})$. $\mathrm{A}(\mathrm{t} / \mathrm{s})$ values were further used as relative target concentration equivalents. As only one defined competitor concentration was applied per experiment, $\mathrm{A}(\mathrm{t} / \mathrm{s})$ values of all samples within one experiment could be compared directly to each other.

\section{Northern blots}

For Northern blotting, $4 \mu \mathrm{g}$ whole RNA per lane were loaded on RNA gels and electrophoresed. Gels were equilibrated and blotted with $20 \times$ SSC onto positively charged nylon membranes using a vacuum blotter from Hoefer (Pharmacia). Digoxigenin-labelled AR and 5RII RNA probes were generated by RT-PCR without competitors using the protocols described above, in which the antisense primers ARIIa and 5RIIE $4 \mathrm{a}$ were tailed by a T7 RNA polymerase recognition sequence at their $5^{\prime}$ ends. The products were electrophoresed on $2 \%$ agarose gels, isolated from the gels, purified by QuiaQuick columns (Quiagen) and blunt ended ('polished') with T4 DNA polymerase (Boehringer-Mannheim). Products were repurified by agarose gels and QuiaQuick columns and finally in vitro transcribed with T7 RNA polymerase (Promega) using digoxygenin labelled rNTPs according to the respective manufacturer's instructions. Northern blot filters were initially pre-hybridized for 1-2 $\mathrm{h}$ and then hybridized overnight with Dig-easyHyb (Boehringer-Mannheim) containing AR or 5RII RNA probes at $68^{\circ} \mathrm{C}$. Blots were washed twice for 510 min with $2 \times \mathrm{SSC} / 0.1 \%$ SDS at room temperature; stringent washings were performed at $68^{\circ} \mathrm{C}$ with $0.1 \times$ $\mathrm{SSC} / 0.1 \%$ SDS for $2 \times 15 \mathrm{~min}$. Chemoluminescence signals of hybridized probes were developed following the 'Digoxygenin Users Guide for Northern-blots' (Boehringer-Mannheim). Gels were stripped and reprobed with $\beta$-actin DNA probe as described above; however, hybridization and washing procedures was performed at $42{ }^{\circ} \mathrm{C}$.

\section{Results}

\section{Evaluation of accuracy of semi-quantitative competitive RT-PCR}

RT-PCRs on AR- and 5RII transcripts were performed on declining amounts of LNCaP cells (AR positive) and hVHF 9-2 (5RII positive) with constant competitor concentrations (0.5 amol AR or 0.02 amol 5RII RNA competitors respectively). As shown in Fig. 1, concentration measurements on AR and 5RII mRNA are proportional to the quantities of whole RNA samples and thus to initial target amounts. At least 4-fold differences in target concentrations can be represented by our method using only one competitor concentration. Three sets of each eight semi-quantitative competitive RT-PCRs were performed to evaluate the methodical variability at three stages of the method: RNA isolation, cDNA synthesis and PCR. One set was performed on eight separate whole RNA samples from cell cultures obtained from a single individual, a second set on a pool of whole RNA and a third set of PCRs on a cDNA pool comprising competitors. A(t/s) values of each RT-PCR set was analyzed for standard deviations from their mean value, which was defined as $100 \%$. For AR RTPCRs, the highest standard deviation could be demonstrated for the RNA pool set $( \pm 10.2 \%)$, the lowest for the cDNA-pool set $( \pm 5 \%)$. The standard deviation of $\pm 9.5 \%$ for the set on separated RNA samples reflects the results from the subsequent cDNA synthesis (RNA pool set). For 5RII semi-quantitative competitive RTPCRs, the standard deviation pattern is similar, but higher at all stages $( \pm 14.8 \%$ (set on separate RNA samples), $\pm 14 \%$ (RNA pool set), $\pm 11 \%$ (cDNA pool set)). These results indicate that cDNA synthesis is the most critical step for semi-quantifications by RT-PCRs. However, maximum standard deviations of as little as $10.2 \%$ for $\mathrm{AR}$ and $14.8 \%$ for $5 \mathrm{RII}$ semi-quantitative competitive RT-PCRs were considered to be low enough to allow proper semi-quantifications. Evaluation of simultaneous competitive RT-PCRs of both AR and 5RII demonstrated the same results as separate competitive RT-PCRs of each transcript.

\section{Influence of androgens and age on $A R$ and 5RII transcription}

To analyze the influence of androgens on AR and 5RII transcription, we incubated the prepubertal cell line hVHF 26-2 in medium containing ascending $\mathrm{T}$ concentrations for $12 \mathrm{~h}$. Then, whole RNA was isolated and three semi-quantitative competitive RT-PCRs for AR and 5RII transcripts per incubation step were applied. As shown in Fig. 2A on the PAA gels from a representative experiment, relations between target and standard are similar for AR and 5RII at all incubation steps. As demonstrated by semi-kinetic RT-PCRs, similar L7 transcript amounts indicate equal whole RNA quantity and quality in these samples. When mean $A(t / s)$ values were depicted as a function of $\mathrm{T}$ concentration, no characteristic difference was found indicating the absence of an influence of $\mathrm{T}$ on AR or 5RII mRNA levels. This result was supported by Northern blots (Fig. 2B). In whole RNA from hVHF 26-2 cells exposed to 0,10 and $100 \mathrm{nM} \mathrm{T}$, we detected two bands at 10.5 and $4.9 \mathrm{~kb}$ responding to the AR probe. The stronger $10.5 \mathrm{~kb}$ band represents physiologically active AR mRNA; the weak signal at $4.9 \mathrm{~kb}$ is most likely caused by an AR transcript degradation product (20). Exposure of the blot to the $5 \mathrm{RII}$ probe unveiled signals at $2.4 \mathrm{~kb}$. After subtraction of background effects, bands specific for both transcripts displayed similar optical densities 


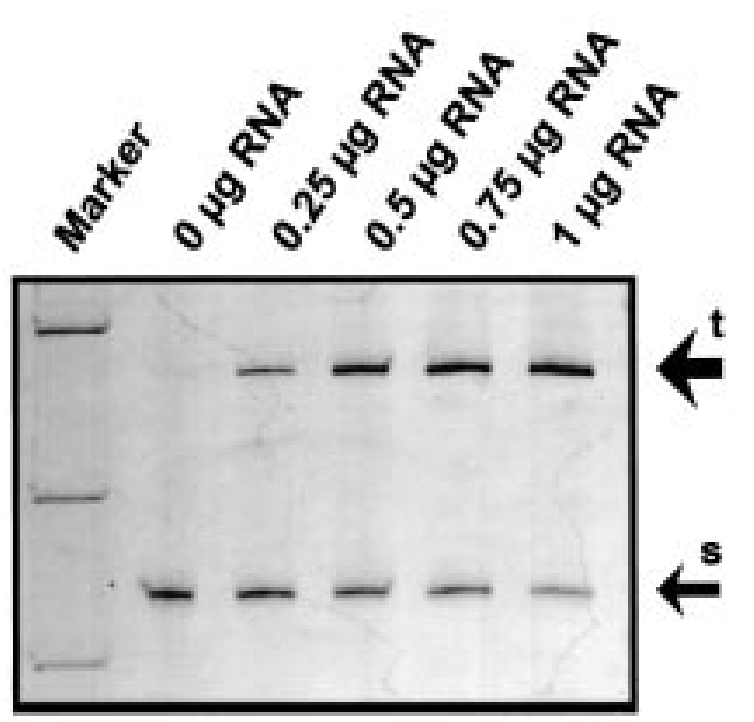

comp. RT-PCR on AR

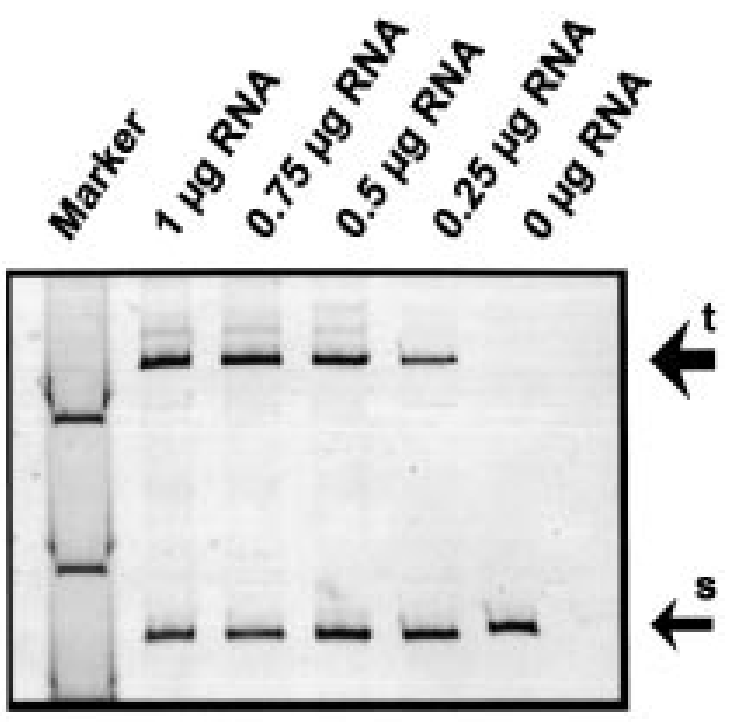

comp. RT-PCR on 5RII

\section{- comp. RT-PCR on AR * comp. RT-PCR on 5RII}

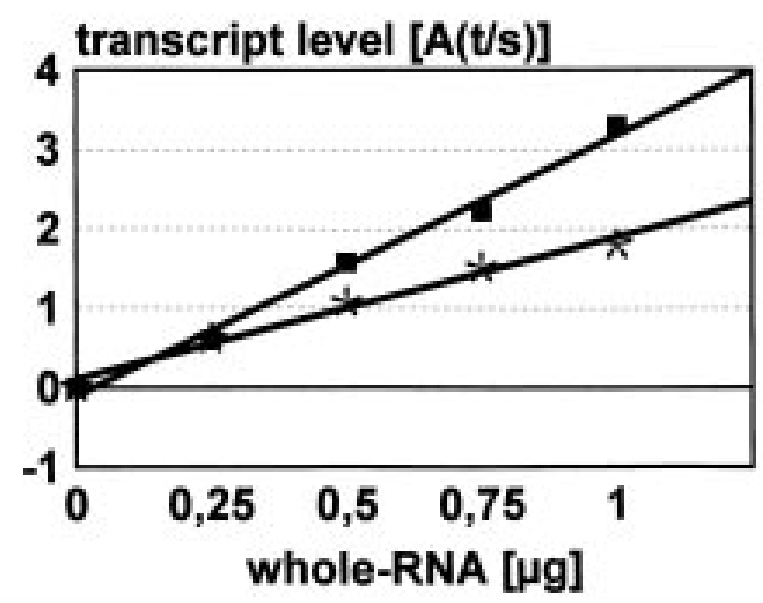

Figure 1 PAA gels with semi-quantitative competitive RT-PCRs on AR (left gel) and 5RII (right gel) and graphical analysis. Declining amounts of whole RNA $(1,0.75,0.5,0.25$ and $0 \mu \mathrm{g})$ from LNCaP cells (AR) and prepubertal GSF cell line hVHF 26-2 (5RII) were each mixed with $0.5 \mathrm{amol} A R$ and 0.02 amol 5RII RNA competitor respectively and submitted to semi-quantitative competitive RT-PCRs. Densities from target and standard (competitor) product bands on PAA gels were quantified and compared, resulting in a value which represents a relative equivalent of transcript concentrations $(A[t / s])$. $A(t / s)$ values are shown below the gels as a function of initial amount of whole RNA per sample. t: target band; s: standard band; M: molecular size markers with DNA fragments of 527, 404 and 307 bp (left gel) or 404 and $307 \mathrm{bp}$ (right gel) length.

(OD) in the $0 \mathrm{nM}, 10 \mathrm{nM}$ and the $100 \mathrm{nM} \mathrm{T}$ sample $(10.5 \mathrm{~kb}$ band $(\mathrm{AR}$ mRNA $)=$ OD $0.84,0.78$ and 0.809 respectively; $2.4 \mathrm{~kb}$ band (5RII mRNA) $=$ OD 1.26, 1.39 and 1.26 respectively). Our findings could be reproduced by experiments based on prolonged $\mathrm{T}$ exposure of prepubertal (hGHF 26-2) and postpubertal (hGHF 33-2)
GSFs for up to $120 \mathrm{~h}$ (Table 1). In an attempt to analyze the effect of the more potent androgen DHT on AR and 5RII transcription, we exposed the prepubertal GSF cell line hGHF 9-2 to $100 \mathrm{nM}$ DHT for increasing periods of time. As shown in Fig. 3, no incubation timedependent correlation of transcript levels could be 


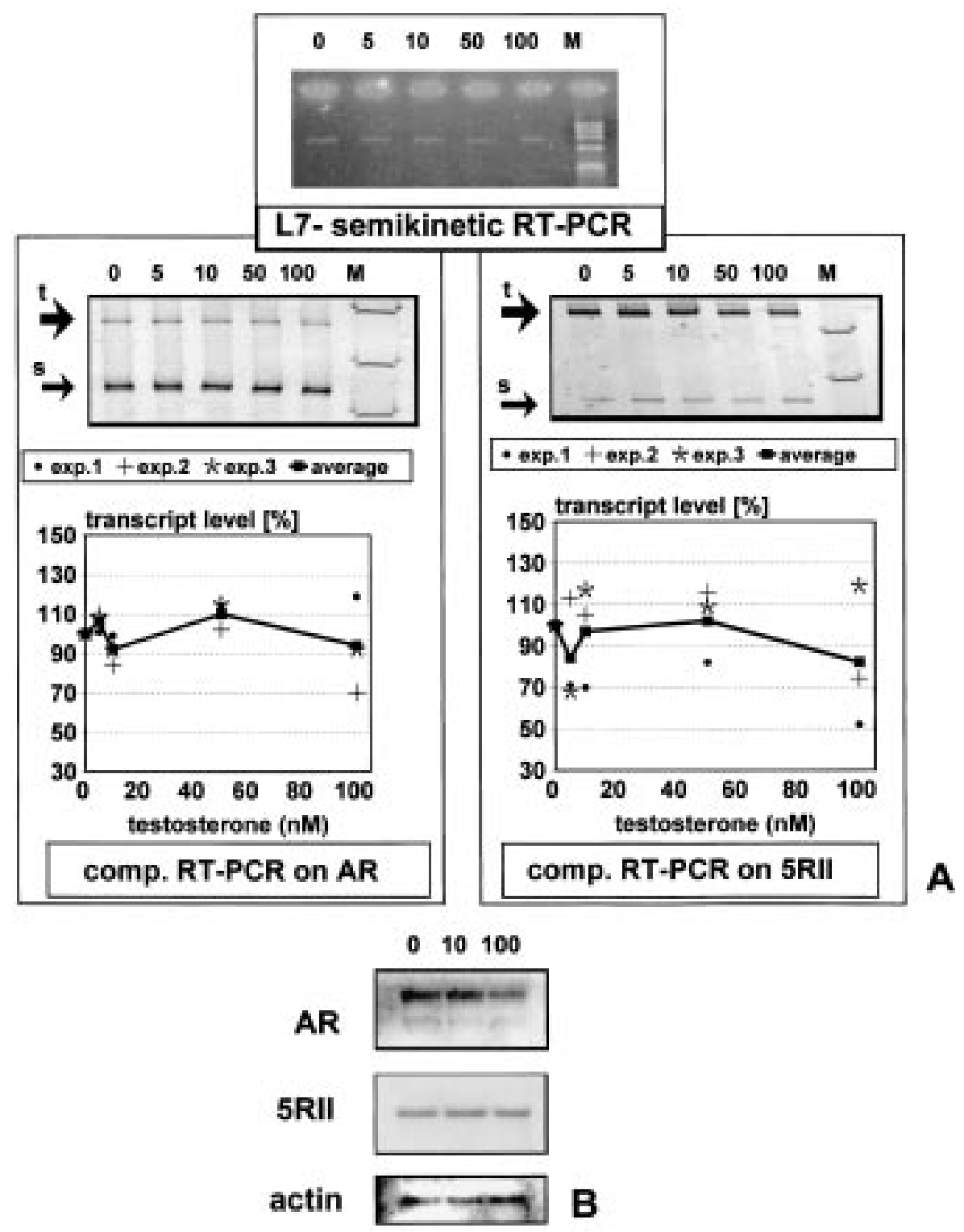

Figure 2 Influence of increasing T concentrations after $12 \mathrm{~h}$ incubation on AR and 5RII mRNA levels in prepubertal GSF (hVHF 26-2). (A) whole RNA samples $(1 \mu \mathrm{g})$ from cells grown in 0, 5, 10, 50 and $100 \mathrm{nM}$ T were submitted to semi-quantitative competitive RTPCRs for AR and 5RII transcripts with 0.2 amol AR and 0.02 amol 5RII competitor simultaneously. Experiments were performed in triplicate. Top panel: $2 \%$ agarose gel with products from semi-kinetic RT-PCRs indicating similar L7 transcript amounts. Bottom panel: one representative PAA gel per transcript is demonstrated. $A(t / s)$ values for $A R$ and $5 R I I$ transcript levels in control cells grown without $T$ were set to $100 \%$ and compared with the three experiments for each T concentration. In the graphs, $A(t / s)$-values for transcripts in T-exposed cells are expressed as a percentage of their control for each $\mathrm{T}$ concentration chosen. Average values of the three measurements are connected by a line for graphical reasons, demonstrating no significant influence of T on AR and 5RII transcription. t: target band; s: standard band; M: molecular size markers with DNA fragments of 527, 404 and 307 bp (left gel) or 404 and 307 bp (right gel) length. (B) Northern blots with specific signals of similar density at $10.5 \mathrm{~kb}$ (AR mRNA) and $2.4 \mathrm{~kb}$ (5RII mRNA) in lanes with whole RNA from GSF incubated with 0,10 and $100 \mathrm{nM} \mathrm{T}$. Actin signaling indicates equal loading.

found, indicating that AR and 5RII mRNA concentrations are not dependent on the presence of DHT.

To test whether the results outlined above could be confirmed by experiments made on other GSF cell lines, we incubated GSF lines from pre- and postpubertal normal male individuals of between 5 months and 51 years old for $48 \mathrm{~h}$ in medium either without $\mathrm{T}$ or with $100 \mathrm{nM}$ T. Transcript levels in GSF grown without T were set to $100 \%$. Mean AR mRNA levels in GSF grown with $\mathrm{T}$ were between 111.9 and $88.7 \%$, mean 5RII transcript levels between $123.9 \%$ and $74.7 \%$ of their control without T. Also, no characteristic effect between 
Table $1 \mathrm{~T}$ incubation experiments on GSFs of two cell lines (hVHF 26-2, prepubertal boy and hVHF 33-2, mature man).

\begin{tabular}{|c|c|c|c|c|c|}
\hline \multirow[b]{2}{*}{ Cell culture } & \multirow{2}{*}{$\begin{array}{c}\text { Age } \\
\text { (years/months) }\end{array}$} & \multirow{2}{*}{$\begin{array}{c}\text { Incubation } \\
\text { concentrations } \\
\text { in androgen } \\
(\mathrm{nM})\end{array}$} & \multirow{2}{*}{$\begin{array}{l}\text { Incubation } \\
\text { time } \\
\text { (h) }\end{array}$} & \multicolumn{2}{|c|}{$\begin{array}{l}\text { Influence of T } \\
\text { on mRNA levels }\end{array}$} \\
\hline & & & & AR & $5 \mathrm{RII}$ \\
\hline hVHF 26-2 & $4 y 4 m$ & $\mathrm{~T}: 0,5,10,50,100$ & $12,24,48,120$ & none & none \\
\hline hVHF 33-2 & $42 y$ & $\mathrm{~T}: 0,5,10,50,100$ & $12,24,48$ & none & n.m. \\
\hline hVHF 33-2 & $42 y$ & DHT: 100 & $\begin{array}{l}0,1,2,3,6,9 \\
12,24,48,120\end{array}$ & none & n.m. \\
\hline
\end{tabular}

Experiments were performed as explained for Fig. 2. n.m., not measurable.

transcript concentrations and the presence or absence of $\mathrm{T}$ in different GSF cell lines was found. In contrast to AR transcription, 5RII mRNA levels in GSFs grown without $\mathrm{T}$ displayed marked individual differences which are additionally dependent on donor ages. Higher transcript levels were found in early infancy with maximum values in GSFs from the donors aged 2 years 7 months and 4 years 3 months. Then, A(t/s) values decline reaching the lowest values at donor ages of 42 and 51 years (Fig. 4). These observations were supported by semi-quantitative competitive RT-PCRs for 5RII on RNA from GSF cell lines hVHF 2-2 (11 months old) and hVHF 33-2 (42 years old) with competitor concentrations decreasing from 0.1 to $0.005 \mathrm{amol} / \mu \mathrm{g}$ RNA (data not shown). For hVHF 2-2 the target amplificate emerged on PAA gels despite competition by a high competitor concentration $(0.1 \mathrm{amol})$; for hVHF 33-2 the target product only appeared reproducible at 0.005 amol competitor per $\mu \mathrm{g}$ RNA.

\section{Discussion}

\section{Simultaneous, competitive RT-PCRs allow accurate semi-quantification of transcripts}

Combined reverse transcription and competitive PCR is a reliable method for specific gene transcript quantification.
In contrast to Northern blots and ribonuclease protection assays $(11,21)$, semi-quantitative competitive RTPCR is especially less labor and often also less material intensive and comprises only two substantial steps and thus only two error sources: cDNA synthesis and PCR. PCR is most critical for proper quantification, as exponential amplification is followed by stages of linear and/or stagnant amplification (plateau phase) at higher cycles. This problem is encompassed by artificial standards (competitors). During the exponential phase and plateau, these standards behave similarly to the targets due to target identical primer recognition sequences $(22,13)$. This was documented by moderate technical variations found at the PCR level ( $\pm 5 \%$ for the AR and $11 \%$ for the 5 RII transcript). As published by Price et al. (23) and verified by us (Fig. 1), relative transcript level differences can be distinguished reliably over at least a 4-fold range by adding just one constant competitor concentration to the samples. Synthesis of cDNA, however, is also subject to variations which may be critical for accurate quantification: reverse transcription with poly-dT primers has been reported to reach only $40-50 \%$ efficacy $(24,25)$. This step is normally standardized by low cycle-number PCRs on reverse transcribed house-keeping gene transcripts (13). We ourselves made kinetic RT-PCRs on house-keeping gene L7 transcripts to assure similar whole RNA sampling

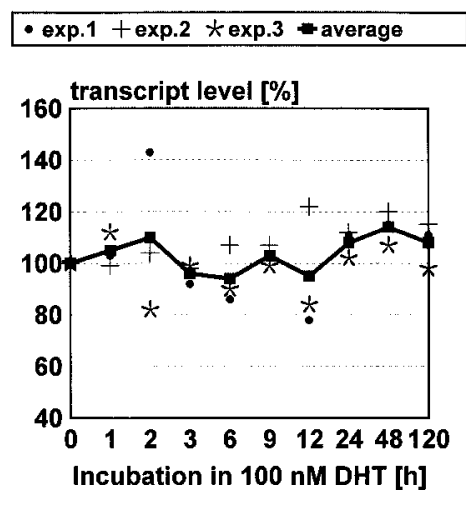

comp. RT-PCR on AR

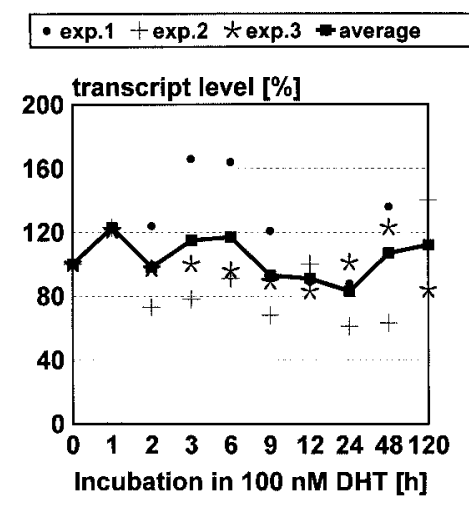

comp. RT-PCR on 5RII
Figure 3 Influence of $100 \mathrm{nM}$ DHT on AR (left side) and 5RII mRNA (right side) levels in prepubertal GSFs (hVHF 9-2) at increasing incubation periods from 1 to $120 \mathrm{~h}$. Experiments were performed in duplicate or triplicate, and average values were connected by a line for graphical reasons to demonstrate that no correlation between DHT incubation time and AR or 5 RII transcription exists. 


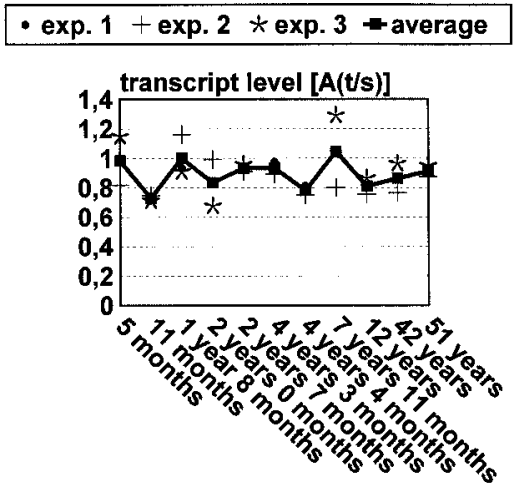

comp. RT-PCR on AR

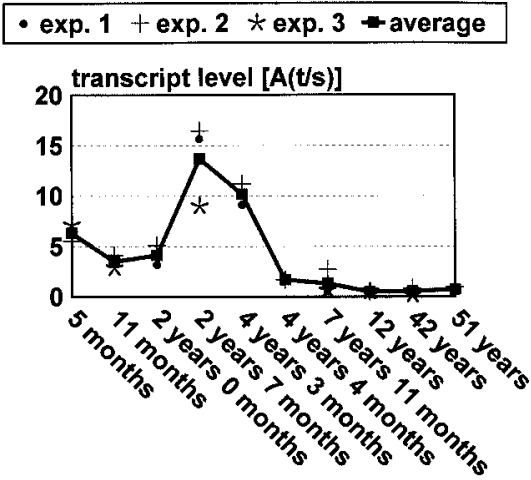

comp. RT-PCR on 5RII

Figure 4 Influence of donor age on AR and 5RII mRNA levels in 11 (AR) or 10 (5RII) GSF cell lines. In the graphs, average values of three measurements per GSF cell line are shown, demonstrating a decline in 5RIl transcript concentration with age (right graph), while AR transcript concentrations are not altered significantly in different age groups (left).

(Fig. 2). However, manual kinetic RT-PCR is imprecise, as differences lower than 2-fold (26) cannot be distinguished reliably. Additionally, possible RT efficiency variances which are specific to different transcripts cannot be outlined by kinetic RT-PCRs on housekeeping gene transcripts. Therefore this step was standardized by the addition of RNA competitors before cDNA synthesis, as reported by Henvel et al. (27). In fact, we could demonstrate that in-tube RT efficacy variances are normalized to tolerable values. However, quantification had to be repeated to provide reliable results. If two transcripts were examined, whole RNA amounts and labour-intensity increased considerably. A preservation of both advantages of our method, fully standardized RT-PCR by RNA competitors and reduced material and time consumption, was made possible by specific-primed RT of AR and 5RII transcripts with RNA competitors in one tube followed by separate PCRs. We achieved reliable semi-quantification of two transcripts per $\mu \mathrm{g}$ RNA. Theoretically, multiple transcripts can be quantified with little expenditure by semiquantitative competitive RT-PCRs.

\section{Natural androgens do not influence $A R$ and 5RII transcription in GSFs}

Our observations indicate that testosterone and dihydrotestosterone, independently of cell line, incubation time or androgen concentration, do not control AR or 5RII transcription in cultured GSFs (Figs 2 and 3, Table 1). Our results are supported by previous studies (28-30), which point to an androgen-independent regulation of $5 \alpha$-reductase activity in skin from external genitalia. In contrast, these former studies indicate that $5 \alpha$ reductase in cells from the pubic skin appears to be under the control of androgens. Seemingly, this is the result of predominant $5 \alpha$-reductase type I expression in this cell type (31); this $5 \alpha$-reductase iso-enzyme seems to underlie androgen-dependent expression control mechanisms. For AR, our results are in accordance with the data from Wolf et al. (10), who did not observe any effect of $96 \mathrm{~h}$ of androgen incubation on AR transcript levels in GSFs. However, Nirdé et al. (32) reported a DHT-driven AR transcription regulation observable at short periods of incubation (0.5-12 h). This contrast may be explained by different experimental designs. Firstly, Nirdé et al. (32) incubated their cells in $1 \mathrm{nM}$ DHT; this is a 5 -fold lower concentration than the lowest $\mathrm{T}$ concentration used by us $(5 \mathrm{nM})$. However, as we demonstrated 5RII transcription in GSFs, T can be expected to be partly reduced to DHT by 5RII translation products. Thus, GSFs should display at least residual or retarded AR transcription regulation in response to T. We could not detect such event, the same holds true for incubation with $100 \mathrm{nM}$ DHT (Fig. 3). Second, Nirdé et al. (32) applied AR transcript quantification on GSFs from newborn boys. Our detailed experiments were performed on GSFs from infants of approximately 4 years of age. It could be possible that AR transcription regulation is controlled by androgens only during a restricted phase ending during early infancy. However, AR transcript levels in GSFs from 5month-old individuals did not differ significantly from those in GSFs from older individuals (Fig. 4), making pronounced changes of AR transcription regulation mechanisms improbable. Additionally, these GSFs also did not display any specific reaction to $100 \mathrm{nM} \mathrm{T}$ administration after $48 \mathrm{~h}$ (data not shown). The results of Nirdé et al. (32) show wide differences of AR transcript level reactions to DHT incubation between four different GSF cultures. Whether these variations and the differences dependent on DHT incubation times are influenced by the technical approach they took remains to be answered. Several deficiencies are 
apparent in the method used by Nirdé et al. (32) for the application of reverse transcribed competitive PCRs, as they did not monitor transcript-specific differences in cDNA efficiency and DNA competitor was added after the RT step. They also measured optical densities of products from RT competitive PCRs on agarose gels, which may present with a high background and additionally do not provide optimal separation of similarly lengthened DNA fragments. These problems are eliminated in the method described here as we used RNA competitors and PAA gels for densitometric evaluations of product bands. Additionally, we analyzed 12 different GSF cultures, in contrast to four cultures tested by Nirdé et al. (32).

Levels of 5RII mRNA showed marked individual variations (Fig. 4). Seemingly, they are predominantly correlated with the donor age. After higher transcription rates in early infancy, 5RII mRNA amounts decrease considerably to the lowest values in GSFs from a 12-year-old boy and a fertile man. These results are in accordance with those of Pinsky et al. (33), who reported a 40 -fold variation of $5 \alpha$-reductase activity between different foreskin GSF strains. Although previous indications for high $5 \alpha$-reductase levels in external genitalia of prepubertal individuals exist $(28-30)$, we could not find direct reports which support or contradict a possible age dependence of 5RII transcript levels in GSFs. Hodgins (34) suspected that high $5 \alpha$-reductase activity in embryonic external genitalia may serve to protect these tissues from the potentially antiandrogenic action of progesterone. Correspondingly, the low 5RII mRNA levels observed by us in GSFs from pubertal and adult donors could reflect the decreased necessity for such protection at older ages. The extremely low 5RII mRNA levels in adult GSFs may also be explained by their insignificance for further maturation of external genitalia. The finding that the highest levels occurred in GSFs from individuals of approximately $2 \frac{1}{2}$ to 4 years old, however, does not fit with these explanations, although it could be explained by individual differences alone.

In contrast, AR transcription is similar in all GSF cultures tested independent of age. For maturation of male external genitalia in embryonic stages, infancy and puberty, constant and reliable AR levels may be critical in GSFs, as they play an important role in the organization of these tissues. The need for such constancy may persist in adulthood to guarantee instant response of genital tissues to androgens. If this is the case, AR mRNA levels should be insensitive to androgen-driven regulation during maturation and adulthood, as this would lead to instabilities in AR expression depending on hormonal variations. Similarly, the last consideration could also explain the absence of androgen-driven autoregulation of 5RII transcription.

In conclusion, impairment of AR or 5RII transcription may well be an important mechanism in virilization disorders. Whether this holds true in respective patients still remains to be investigated.

\section{Acknowledgements}

We are grateful to Dr Hartmut Merz for generously allowing us to use the laboratory equipment from the Department of Pathology of the Medical University of Lübeck. We are indebted to Dr Almassry and Dr Tuchen in Lübeck, Germany, for kindly supplying us with human foreskins. We thank Mrs Kleinschmidt and Mrs Angermann for instant and committed arrangement of photographs and Nicole Getschmann for her excellent technical assistance. This work was supported by the Deutsche Forschungsgemeinschaft (Hi 497/32,3 and $\mathrm{Hi} 497 / 4-2$ to $\mathrm{OH}$ )

\section{References}

1 Simental JA, Sar M, Lane MV, French FS \& Wilson EM. Transcriptional activation and nuclear targeting signals of the human androgen receptor. Journal of Biological Chemistry 1991 266 510-518.

2 Quigley CA, De Bellis A, Marshke KB, El-Awady MK,Wilson EM \& French FS. Androgen receptor defects: Historical, clinical and molecular perspectives. Endocrine Reviews 199516 271-321.

3 Beato M, Chavez S \& Truss M. Transcriptional regulation by steroid hormones. Steroids 199661 240-251.

4 Schweikert HU. Intersexualität: Gonadendysgenesien und Testikuläre Feminisierung. Gynäkologie 199528 17-26.

5 George FW, Russell DW \& Wilson JD. Feed-forward control of prostate growth: Dihydrotestosterone induces expression of its own biosynthetic enzyme, steroid 5-alpha-reductase. PNAS 1991 88 8044-8047.

6 Quarmby VE, Yarbrough WG, Lubahn DB, French FS \& Wilson EM. Autologous down-regulation of androgen receptor messenger ribonucleic acid. Molecular Endocrinology $1990422-$ 28 .

7 Gonzalez-Cadavid N, Vernet D, Fuentes Navarro A, Rodriguez JA, Swerdloff RS \& Rajfer J. Up-regulation of the levels of androgen receptor and its mRNA by androgens in smooth-muscle cells from rat penis. Molecular and Cellular Endocrinology $199390219-229$.

8 Varriale B. Autoinduction of androgen receptor mRNA in primary cultures of hamster (Mesocricetus auratus) harderian gland cells. General and Comparative Endocrinology 1996102 386-393.

9 Kongrad A, Wilson CM, Wilson JD, Allman DR \& McPhaul MJ. Androgen increases androgen receptor protein while decreasing receptor mRNA in LNCaP cells. Molecular and Cellular Endocrinology $19917679-88$

10 Wolf DA, Herzinger T, Hermeking H, Blaschke D \& Horz W. Transcriptional and posttranscriptional regulation of human androgen receptor expression by androgen. Molecular Endocrinology 19937 924-936.

11 Sambrook J, Fritsch EF \& Maniatis T. Analysis of RNA / Northernhybridisation. In Molecular Cloning: A Laboratory Manual, edn 2, vol 1, pp 7.37-7.39. Eds N Ford, C Nolan, M Ferguson. New York: Cold Spring Harbor Laboratory Press 1989.

12 Wick M, Bürger C, Brüsselbach S, Lucibello FC \& Müller R. Identification of serum-inducible genes: different patterns of gene regulation during $\mathrm{G}_{0}-\mathrm{S}$ and $\mathrm{G}_{1}-\mathrm{S}$ progression. Journal of Cell Science 1994107 227-239.

13 Siebert PD. Quantitative PCR without the use of internal standards. And: Competitive PCR. In Quantitative RT-PCR; Methods and Applications, edn 1, pp 12-16 and 26-42. Eds Y Munch, K Mayo, A Miller. Palo Alto: Clontech Laboratories Inc., 1993. 
14 Celi FS, Zenilman ME \& Shuldiner AR. A rapid and versatile method to synthesize internal standards for competitive PCR. Nucleic Acids Research 1993211047.

15 Lubhahn DB, Brown TR, Simental JA, Higgs HN, Migeon JC, Wilson EM et al. Sequence of the intron/exon junctions of the coding region of the human androgen receptor gene and identification of a point mutation in a family with complete androgen insensitivity. PNAS 198986 9534-9538.

16 Nitsche EM, Moquin A, Adams PS, Guenette RS, Lakins JN, Sinnecker GHG et al. Differential Display RT-PCR of total RNA from human foreskin fibroblasts for investigation of androgendependent gene expression. American Journal of Medical Genetics $199663231-238$.

17 Labrie F, Sugimoto Y, Luu-The V, Simard J, Lachance Y, Bachvarov D et al. Structure of human type II 5 alpha-reductase gene. Endocrinology 1992131 1571-1573.

18 Hiort O, Huang Q, Sinnecker GHG, Sadeghi-Nejad A, Kruse K, Wolfe HJ et al. Single strand conformation polymorphism analysis of androgen receptor gene mutations in patients with androgen insensitivity syndromes: Application for diagnosis, genetic counceling and therapy. Journal of Clinical Endocrinology and Metabolism 199377 262-266.

19 Hiort O, Wodtke A, Struve D, Zöllner A \& Sinnecker GHG, the German Collaborative Intersex Study Group. Detection of point mutations in the androgen receptor gene using non isotopic single strand conformation polymorphism analysis. Human Molecular Genetics 19943 1163-1166.

20 Faber PW, van Rooij HCJ, van der Korput HAGM, Baarends WM, Brinkmann AO, Grootegoed JA et al. Characterization of the human androgen receptor transcription unit. Journal of Biological Chemistry 199117 10743-10749.

21 Dankbar B, Sohn M, Nieschlag E \& Gromoll J. Quantification of androgen receptor and follicle-stimulating hormone receptor mRNA levels in human and monkey testes by a ribonucleaseprotection assay. International Journal of Andrology 199518 88-96.

22 Wang AM, Doyle MV, Mark DF. Quantitation of mRNA by the polymerase chain reaction. PNAS 198986 9717-9721.

23 Price T, Aitken J \& Simpson ER. Relative expression of aromatase cytochrome $\mathrm{P} 450$ in human fetal tissues as determined by competitive polymerase chain reaction amplification. Journal of Clinical Endocrinology \& Metabolism 199274 879-883.

24 Berger SL, Wallace DM, Puskas RS \& Eschenfeldt VH. Reverse transcriptase and its associated ribonuclease $\mathrm{H}$ : Interplay of two enzymes activity controls the yield of single-stranded complementary deoxyribonucleic acid. Biochemistry $1983222365-2372$.

25 Bouaboula M, Legoux P, Pességué B, Delpech B, Dumont X,
Piechaczyk M et al. Standardization of mRNA titration using a polymerase chain reaction method involving co-amplification with a multispecific internal control. Journal of Biological Chemistry 1992267 21830-21838.

26 Salomon RN, Underwood R, Doyle MV, Wang A \& Libby P. Increased apolipoprotein E and c-fms gene expression without elevated interleukin 1 or 6 mRNA levels indicates selective activation of macrophage functions in advanced human atheroma. PNAS 199289 2814-2818.

27 Henvel JPV, Tyson FL \& Bell DA. Construction of recombinant RNA templates for use as internal standards in quantitative RTPCR. BioTechniques 199314 395-398.

28 Mauvais-Jarvis P, Mowszowicz I \& Kuttenn F. Significance of $5 \alpha$ reductase activity in human sexual differentiation. In Sexual Differentiation. Basic and Clinical Aspects. Serono Symposium, pp. 247-260. Eds M Serio, M Motta, M Zanisi, L Martini. New York: Raven Press, 1984.

29 Kuttenn F \& Mauvais-Jarvis P. Testosterone $5 \alpha$-reduction in the skin of normal subjects and of patients with abnormal sex development. Acta Endocrinologica 197579 164-176.

30 Kuttenn F, Mowszowicz I \& Mauvais-Jarvis P. Androgen metabolism in human skin. In Percutaneous Absorption of Steroids, pp. 99121. Eds P Mauvais-Jarvis, CFH Vickers, J Wepierre. London: Academic Press, 1980.

31 Mestayer C, Berthaut I, Portois MC, Wright F, Kuttenn F, Mowszowicz I et al. Predominant expression of 5 alpha-reductase type 1 in pubic skin from normal subjects and hirsute patients. Journal of Clinical Endocrinology and Metabolism 199681 19891993.

32 Nirdé P, Georget V, Téouranne B, Galifer RB, Belon C \& Sultan C. Quantitation of androgen receptor messenger RNA from genital skin fibroblasts by reverse transcription-competitive polymerase chain reaction. Journal of Steroid Biochemistry and Molecular Biology 199866 35-43.

33 Pinsky L, Kaufman M, Straisfeld C, Zilahi B \& Hall CS. $5 \alpha$ reductase activity of genital and nongenital skin fibroblasts from patients with 5alpha-reductase deficiency, androgen insensitivity or unknown forms of male pseudohermaphroditism. American Journal of Medical Genetics 19781 407-416.

34 Hodgins MB. Binding of androgens in $5 \alpha$-reductase-deficient human genital skin fibroblasts: inhibition by progesterone and its metabolites. Journal of Endocrinology 198294 415-427.

Received 24 November 1999

Accepted 20 April 2000 